\title{
9. Care for older people in early twenty-first-century Europe: dimensions and directions of change Teppo Kröger and Angela Bagnato*
}

\section{INTRODUCTION}

Provisions and patterns of care for older people have recently undergone significant change all over Europe (Ranci and Pavolini, 2013). Many European nations have been reaching out for innovations in care as their populations continue to age at an increasing speed and new models are clearly necessary in order to deal with growing needs (Leichsenring et al., 2013; Gori et al., 2016). On the one hand, countries like Spain (Deusdad et al., 2016a) and Ireland (Timonen et al., 2012), which earlier had not been particularly active in developing long-term care, have launched new policies and, on the other hand, countries that had introduced care policies earlier, like Britain and the Nordic countries, have been reforming their provisions (Anttonen and Karsio, in this volume; Yeandle, 2016). At the same time, countries in Central Eastern Europe have been trying to depart from an overly institution-based provision, that is, from the legacy of the socialist period (Kubalčíková et al., in this volume). One issue that has been prominent in reform efforts is the redefinition of the 'vertical division of authority' or 're-scaling of responsibility' between local and central government (see Martinelli, Chapter 1, as well as Sabatinelli and Semprebon, in this volume; Kazepov, 2010). The European Union has also been searching for a role in long-term care policy, attempting to influence policy-making in member states at least indirectly (see Gómez-Barroso et al., in this volume). In addition, the development of care systems has been affected by the progress of neo-liberal thinking and NPM-inspired governance models (see Martinelli, Chapter 1, in this volume).

However, the conditions of policy-making were changed radically when the financial crisis spread to Europe in 2008. Many national economies were hit hard, especially in Southern Europe. Progressive policy reforms were halted in a number of policy fields, also in care for older people, and 
austerity measures came into focus instead. However, a general Europeanwide view on the implications of the economic crisis for care policy developments has been missing. This chapter makes a contribution to filling this knowledge gap by mapping the main directions of change in long-term care in different parts of Europe during the early twenty-first century.

The analysis presented here is based on information reported in working papers produced by national teams in the course of the COST Action IS1102 SO.S. COHESION - Social services, welfare states and places. All working papers that describe developments in the care for older people were selected to be reviewed in this chapter. These COST Action papers or presentations (CAPs hereafter) cover 11 European countries in total, representing the Nordic countries (with Denmark, Finland, Iceland), Central/Central Eastern Europe (with the Czech Republic, Germany, Slovakia) and the Mediterranean region (Greece, Italy, Malta, Spain), plus the United Kingdom. ${ }^{1}$

Being based on the information that these reports offer, this chapter is thus the result of a collective effort and it aims to summarise the similarities and differences of recent changes in care provisions for older people in these 11 countries. Summing up these reports has not been uncomplicated, due to the richness of their details and because some of them are local case studies in character while others describe developments at the national level. Their contents and, sometimes, terminology differ. Moreover, there are many local and regional variations within countries, Italy being a prime example with its substantial differences between the North and the South of the country. Furthermore, these 11 countries do not represent the whole of Europe. As a result, the picture drawn here of changes in European care provisions remains unavoidably incomplete and fractional.

Nevertheless, these reports are a valuable source of information on recent policy developments in different parts of Europe, written by social policy and long-term care researchers. We made a thematic analysis of these reports, aiming to interpret and summarise their key findings. According to Braun and Clarke (2006, p.79), thematic analysis is a method for 'identifying, analysing and reporting patterns (themes) within data. It minimally organises and describes your data set in (rich) detail. However, frequently it goes further than this, and interprets various aspects of the research topic'. This description fits the way this chapter was written.

Based on a careful reading of extended abstracts of the reports, common themes were identified that appeared in a number of the reports. Five such themes became especially visible. Next, all the full reports were read carefully and summarised using a framework that consisted of these five key themes. Most key discussions of the reports centred around these five themes and each of them was featured in several reports. Each theme 
appeared as a specific dimension of policy development and design, consisting of a dichotomous double concept and of the distance in between. These five dimensions were: (1) decentralised care-centralised care; (2) social care-health care; (3) outsourcing-in-house provision of care; (4) home-based care-institutional care; and (5) formal care-informal care. These five policy dimensions are thus based on the themes we identified in our reading and analysis of the reports, representing an interpretation of key issues of recent change in long-term care.

The chapter is structured according to the framework that emerged from our thematic analysis of the reports and presents their observations one key dimension after another. The contents of this chapter overlap partly with previous chapters of this collection as they are based on the same COST Action local and national studies. However, earlier chapters focus on a particular theme or group of countries, whereas this chapter aims to synthesise the general observations on recent developments of care from all the participating countries that addressed care for older people.

\section{DECENTRALISED CARE-CENTRALISED CARE}

How have European care systems changed recently, seen through the lens of decentralisation? Unlike most social security benefits, care services are only rarely delivered to citizens through national welfare agencies. Instead, they are part of the local welfare state, organised and produced usually by local and regional authorities. Nevertheless, this is done in an administrative framework created by the central state through legislation, central regulation and central grant systems (Burau and Kröger, 2004; Kazepov, 2010; Kröger, 2011). Care is thus an issue of multilevel governance where the vertical division of labour between the national and sub-national levels of government - and increasingly supra-national levels like the EU - plays a major role (Kutsar and Kuronen, 2015; Martinelli, Chapter 1, in this volume). Local and regional levels always have at least some discretion in the implementation of care policies but the national government may aim to either limit or broaden the scope of this discretion.

The COST Action working papers show that in the twenty-first century, local/regional governments have been given additional responsibilities for care for older people in several European countries. In Italy, for example, after 2001, regional governments were given authority over all social services. However, a corresponding transfer of resources did not accompany this change. As a result, regional governments, especially in the poorer regions of Italy, have not been able to deliver adequate care services. National government has avoided responsibility also by not defining 
national quality benchmarks. In the absence of centrally defined criteria for a minimum level of services, local and regional variations in coverage and quality of services have further increased in Italy (CAP Bagnato et al., 2014).

The developments in the Slovak and Czech Republics are similar to the situation in Italy: in both countries long-term care has experienced a process of legislative and financial decentralisation. Local authorities have been delegated the responsibility for care but, like in Italy, without guaranteeing the necessary financial resources and thus, without guaranteeing that local authorities are really able to deliver adequate services (Kubalčíková et al., in this volume; Szüdi et al., 2016).

In the $U K$, the central government has imposed new constraints on the spending of local authorities. These spending caps represent a kind of re-centralisation in financing, limiting the action of local authorities. At the same time, local authorities have nevertheless been granted greater autonomy and responsibility in implementation (Kispéter and Yeandle, 2015; CAP Yeandle, 2014; Yeandle, 2016). Also in Denmark, local authorities are under increasing pressure and economic control as the central state is aiming to cut local spending (CAP Jensen and Fersch, 2013).

Danish municipalities and Southern Italian regions are certainly in a different situation: the former provide universal free-of-charge care services to a large proportion of their population aged 65 and over, while the latter can offer only limited care provisions to their inhabitants. Nevertheless, both - as well as local authorities in a number of other European countries - face rather similar tendencies: national governments have been eager to delegate the responsibility for care for older people to subnational units, that is, to regional and local authorities (Ranci and Pavolini, 2013). However, this decentralisation of responsibility has not been accompanied by a corresponding transfer of economic resources to the local and regional levels. On the contrary, despite continuously increasing care needs, several central governments have cut their funding to long-term care and capped local spending, thus reducing in practice the opportunities of local and regional governments to meet the needs of their older citizens (see also Sabatinelli and Semprebon, in this volume).

\section{SOCIAL CARE-HEALTH CARE}

Needs for social care in old age are associated with difficulties with health, which makes social and health care fundamentally interrelated. In most countries, both social welfare agencies and health care providers are involved in the provision of care services, helping people in old age to 
manage their daily activities. The exact boundary between the two sectors is nevertheless up to national and local definitions. In many European countries, the health sector and the social sector have major difficulties in their collaboration, do not manage to provide integrated services and continue to work separately from each other (Leichsenring, 2004; Colombo et al., 2011; Rodrigues et al., 2012; Ranci and Pavolini, 2013).

Very often social services are provided by local governments, while health services are the responsibility of regions or sometimes the central state. Such an administrative separation has brought additional complications for the co-operation of the two sectors and made their full integration impossible. Recently, some efforts have been made to overcome this institutional dualism. For example, the Slovak Republic attempted in 2005 to integrate health care services, financed by health insurance payments, and social care services, which are provided by the social welfare system and funded through regional and local taxation and co-payments of care users. However, this integration effort failed and, in the end, the proposed law was not enacted (CAP Kováčová et al., 2014; Szüdi et al., 2016). Italy has launched a new service concept of 'integrated socio-health domiciliary care' (assistenza domiciliare integrata), but in regions like Calabria this new service is still organised by regional health districts alone, seldom in collaboration with municipal welfare agencies (CAP Bagnato et al., 2014).

In Iceland, in the early 2000 s the largest municipalities assumed responsibility for all social and health care, while previously the responsibilities had been divided between the state, the municipality and the providers. A similar integration of management of the two sectors is planned to take place at the national level in the near future. However, in this case, it is necessary to remember that the whole nation has only about 329000 citizens, which explains why the central state has until now taken an exceptionally large role in care provision (CAP Sigurðardóttir, 2014).

In some countries, particularly in Southern Europe, the slow development of social care and the resulting lack of access to its services have produced the phenomenon of 'social hospitalisation' (Colombo and Mercier, 2012). In Spain, for example, social care has remained unavailable to many, and using health care services, in particular hospitals, has been the usual way to try to obtain assistance for the activities of daily life, causing an overuse of health care and long waiting lists (Garcés et al., 2013; CAP Ródenas et al., 2013). However, due to austerity measures brought by the recent economic crisis, the Spanish public health care system has lately lost many of its universalistic features: access depends now on membership with the social security system, the unemployed being excluded. Co-payments for medications have also been introduced. These and other recent changes have made public health care inaccessible or unaffordable 
to many older people and have thus ended a large part of the earlier 'social hospitalisation' (CAP Deusdad and Zafra, 2013; Deusdad et al., 2016b).

On the other hand, in several parts of Europe the crisis seems to have affected the social care component of services at least as much as the health care component. Home-based social care has been cut in several countries. For example, local authorities in Denmark and Finland have made their spending cuts in home care primarily in services for household tasks and social support, not in health-related services for personal care (Kröger and Leinonen, 2012; CAP Jensen and Fersch, 2013; CAP Kröger et al., 2013).

The duality of social care and health care has not disappeared during the new century. Some countries have recently aimed to integrate these two domains, particularly within home-based care for older people. These efforts have not always been successful but many integration efforts and experiments are going on (e.g. Leichsenring and Alaszewski, 2004; Hixon, 2016). Austerity measures have in many places heightened the earlier tensions between social and health care as both domains are trying to manage under cuts and are retargeting their activities. So far, the question of how to bring social and health care into close co-operation and integrate their services in a way that covers both the health needs and social needs of the older population remains mostly unanswered.

\section{OUTSOURCING-IN-HOUSE PROVISION OF CARE}

For-profit long-term care provision has traditionally been untypical in Europe, which has instead been characterised by public provision (especially in Northern and Eastern Europe), provision by non-profit organisations (in Central European countries) or a delegation of care tasks to the family (in Southern Europe and parts of Eastern Europe) (EC, 1999). However, several European countries have recently started to outsource publicly funded care services to for-profit or non-profit providers through competitive tenders, leading to a decrease of the share of direct 'in-house' provision by local authorities (e.g. Meagher and Szebehely, 2013).

In the late 1980s and early 1990s, Britain was the first country in Europe to start a determined policy push towards broadening the role of the 'independent' sector in care (Means et al., 2002). Many local authorities in Britain are still continuing to contract out their care provisions to forprofit (and non-profit) organisations under 'public-private partnerships'. Central government guidance has urged local authorities to keep stimulating local care markets and to develop new models of 'co-production'. For example, in Leeds in 2006 the City Council provided 79 per cent of home 
care hours itself while the for-profit and non-profit sectors provided 21 per cent. By 2011 this situation had effectively reversed, with the private sector providing 75 per cent and the local authority only 25 per cent (Yeandle, 2016, p. 223).

In 2000, Italy enacted national legislation that encouraged outsourcing. In regions like Calabria where public care services were very limited, the new legislation actually led to an enlargement of publicly funded services: the law was used to initiate new services, the provision of which was delegated to non-profit organisations. However, this way to extend services came to an end with the economic recession, as a result of budget cuts. Austerity has recently placed many Italian non-profit organisations and their employees in a vulnerable position as competitive bidding procedures have led to a worsening of contractual relations and, as a result, to decreasing salary levels, longer shifts and a move from permanent to temporary work contracts. Moreover, the payments from local authorities to nonprofit organisations have often been delayed or fully suspended, which has brought many organisations to the verge of bankruptcy (CAP Martinelli, 2012; Gambardella et al., 2013; CAP Bagnato et al., 2015).

Non-profit organisations have faced difficulties in other countries, as well. For example, in Germany, since the 1995 introduction of the longterm care insurance scheme, commercial providers have been admitted to the field of care services for older people, hitherto dominated by the nonprofit sector. The traditional large German non-profit players have not disappeared, but have adapted their management policies to market-inspired models (CAP Mätzke, 2012; CAP Bode, 2013).

Outsourcing of publicly funded care services has become a powerful trend in long-term care for older people in Europe. Local and regional authorities in different parts of Europe increasingly use competitive tendering of care provisions, and this tendency has given for-profit organisations a stronger position. As a result of outsourcing, for-profit services are growing rapidly in several countries in Europe. The new situation has also challenged non-profit organisations. Their non-profit provisions have traditionally supplemented public provisions in a number of countries - or even formed the bulk of services in some countries - but now they have to compete against for-profit providers, which has led to a reduction in differences between the for-profit and non-profit sectors.

\section{HOME-BASED CARE-INSTITUTIONAL CARE}

In the last decades, care policy for older people has emphasised deinstitutionalisation all over Europe. Institutional care has come to be seen 
as paternalistic, unable to promote quality of life, self-determination or quality of care. Furthermore, higher budgetary constraints have strengthened the push to find less expensive alternatives to institutional provisions. 'Ageing in place' has instead become the slogan of new policies (Colombo et al., 2011; Deusdad et al., 2016a). As a result, many governments in Europe have issued policy documents and programmes that promote deinstitutionalisation, such as the 'National action plan for the transition from institutional to community-based care 2012-15' (Národný akčný plán prechodu z inštitucionálnej na komunitnú starostlivost'v systéme sociálnych služieb na roky 2012-2015) in Slovakia.

Following the 'ageing in place' principle, institutional provisions are being cut in different parts of Europe. The Czech Republic, representing a country where institutional care used to dominate the care service scene, has made drastic cuts in the number of places in long-term care institutions, albeit waiting lists remain long (CAP Kubalčíková and Havlíková, 2013; Kubalčíková and Havlíková, 2016). In Iceland, the number of nursing home beds decreased somewhat from 2006 to 2011, while needs have considerably increased, and access has become more strictly controlled than earlier (CAP Sigurðardóttir, 2014). In Finland, too, the number of nursing homes has gone down, leading to an increasing number of older people with high levels of needs living at home and in intensive service housing units (CAP Kröger et al., 2013; CAP Anttonen and Häikiö, 2014; Anttonen and Karsio, 2016). In several Southern European countries there never was a large coverage of institutional services, and the de-institutionalisation policy, together with the economic crisis, have prevented them from growing.

Growing waiting lists are the unintended result of shrinking institutional provisions. Needs for institutional care have not vanished but instead there seems to be a widening gap between needs and actual provisions. In Malta, which has fewer than 450000 inhabitants, the government has calculated that 300 new residential beds would be needed every year over the next ten years in order to keep pace with the ageing of the population - but such an increase in beds is not taking place (CAP Pace and Vella, 2014; Pace et al., 2016). In Catalonia, the regional government ended its financial support for residential care in 2013, which led to further lengthening of waiting lists that were already long (CAP Deusdad and Zafra, 2013; Deusdad et al., 2016b). The recession brought the upgrading and expansion of Icelandic nursing homes to a standstill, as well, which resulted in longer waiting lists and in poorer health of those on the waiting lists (Sigurðardóttir et al., 2016). In some parts of Italy the undersupply of institutional care is a critical issue: for example, in the city of Reggio Calabria, with 185000 people, there are only two publicly supported residential units for older people, 
with a total of 42 beds (Bagnato et al., 2015). In the Czech Republic, people do not trust home care services to provide adequate support in case of high care needs, which has resulted in long waiting lists for institutional care and in the emergence of private residential quasi-services of questionable quality. (CAP Kubalčíková and Havlíková, 2013; Kubalčíková et al., in this volume).

Waiting lists for institutional care show that home-based services have fallen short of the expectation that they could support 'ageing in place' on a grand scale. Institutional care seems to continue to be required in the case of high care needs. This 'failure' of home-based care is to a large extent explained by the fact that, usually, the resources of home care have not been increased to meet the growing needs caused by population ageing and de-institutionalisation. In some places these resources have even been cut down during the economic crisis. In the city of Reggio Calabria in Italy, for example, the number of users of publicly supported home-based social care decreased by more than a half from 2009 to 2014 and the remaining beneficiaries of home care services, all with extensive care needs, receive only three hours of services per week on average (Bagnato et al., 2015).

Some countries, particularly in the Nordic region, that earlier used to provide home care support for both personal care and household tasks, have recently prioritised one area above the other. In a local Danish case study it was found that cuts have been made in practical home help but not in personal care (CAP Jensen and Fersch, 2013). Similarly in Finland, municipal home care services have minimised providing help in several household tasks such as cleaning and shopping and have focused their resources on personal care (CAP Anttonen and Häikiö, 2014; CAP Kröger et al., 2013). In Iceland, on the other hand, assistance at home has been available mainly for domestic tasks, such as cleaning, cooking, shopping and laundry, and less for personal care, getting out of bed, toilet visits, clothing and feeding (CAP Sigurðardóttir, 2014).

The emphasis on 'ageing in place' and de-institutionalisation, accepted widely as a policy principle all over Europe (e.g., Means, 2007; Troisi and von Kondratowitz, 2013), has created a general understanding that institutional care is outdated and no longer necessary. However, the actual situation in different parts of Europe shows growing waiting lists for institutional care as families do not find that their older members receive adequate services at home. Expectations of the capability of home care to support people with high needs seem to have been exaggerated. The inability of European countries to increase resources for home-based service provisions in step with growing needs has clearly contributed to this 'failure of home care'. Instead of the necessary investments, the development of home care services has been characterised by cuts and implementation of 
stricter access criteria. Situations vary in individual countries, but overall both institutional provisions and home-based care services have ended up as targets of austerity measures throughout Europe.

\section{FORMAL CARE-INFORMAL CARE}

The term 'formal care' refers usually to care services provided by public, forprofit or non-profit organisations, while 'informal care' may refer either to care from the family and social networks or to grey market care, performed outside the formal economy (Colombo et al., 2011). Concerning the first component of 'informal care', research has shown that in all countries, Nordic countries included, care is provided overwhelmingly by the family and that formal care provisions represent only a minor share of the total volume of support for older people. When informal family care has been recognised as the real mainstream of care, the interplay between formal and informal care has become a key issue in long-term care policy (Kröger, 2001; Bettio and Verashchagina, 2012). The second component, grey market care, has always occurred in some form but recently it has become more important as families in many European countries have started to employ migrant women to provide care for older people. The phenomenon has been particularly present in Southern Europe in countries like Italy and Greece but it occurs to some extent in many other European countries (Pfau-Effinger et al., 2009; Bettio and Verashchagina, 2012; Ranci and Pavolini, 2013).

Cuts in the provision of institutional and home-based public care do not leave families unaffected. As Icelandic home care services are primarily focused on household tasks, a large proportion of care is expected to come from the family (CAP Sigurðardóttir, 2014; Sigurðardóttir and Kåreholt, 2014). In a local case study from the Czech Republic the situation was found to be the same: there too home care services focus on providing assistance with housekeeping and shopping, while assistance with personal care remains very limited (CAP Kubalčíková and Havlíková, 2013). On the other hand, in Denmark household tasks are currently left to the families of older people to take on (CAP Jensen and Fersch, 2013). Such policy decisions on the limitation of available support are made with little concern for whether older people really have families that can take on these responsibilities.

In some countries, informal family carers have received new rights and forms of support, such as for example in Britain, in Finland and in Germany. In the $U K$, family carers have since the turn of the century had some, albeit limited, employment rights through new legislation and 
they have also gained the right to have their own needs assessed by local authorities. According to the national census 2011 data, there are nevertheless considerable unmet needs for support among carers (Yeandle et al., 2013; CAP Yeandle, 2014; Yeandle, 2016). In Finland, the 2005 revision of the Informal Care Act (Laki omaishoidon tuesta) extended carers' rights for respite and made regulation of their financial support and additional services clearer, though these did not end local variations. In 2011, care responsibilities for older family members were modestly recognised in Finland's labour legislation, when employees were offered the right to unpaid care leave, which, however, requires the agreement of the employer (Kröger and Yeandle, 2013; CAP Kröger et al., 2013).

Germany reformed its long-term care insurance scheme in 2008 in order to improve the situation of frail older people and to support their carers. This reform introduced new forms of unpaid leave for people who take care of a family member, thereby preserving a key role for family members in providing care and helping them to combine their jobs with their care tasks (CAP Bode, 2013). Malta has also launched a pilot project to offer a subsidy for qualified domiciliary carers who look after people put on a waiting list for a residential home, but other measures supporting people who care for an older family member have not yet been forthcoming (CAP Pace and Vella, 2014; Pace et al., 2016).

Spain is an example of a country that launched progressive policy reforms in the early 2000s, in particular with the 2006 Law of promotion of personal autonomy and care for older and disabled people (Ley de Promoción de la Autonomía Personal y Atención a personas en situación de dependencia), but was later hit by the economic crisis. As a result of the 2006 legislation, some informal family carers, mostly wives or daughters, started to receive care allowances and were for the first time included in pension schemes. However, these rights were short-lived as, due to the cutbacks of social spending, from 2012 caring relatives were excluded from the social security system (CAP Deusdad, 2013; CAP Deusdad and Zafra, 2013; Deusdad et al., 2016b).

The economic crisis has also brought some unforeseen changes in the behaviour of families. Though long waiting lists for institutional care are reported in Southern Europe, it has been noticed that in both Spain and Italy cash-for-care benefits to older people (In Italy, Indennità di accompagnamento), as well as pensions of older family members, are now used to help children and grandchildren economically, that is, to even out the gaps in family economies caused by the crisis. As a result, willingness to use institutional care or other formal care services in these countries has decreased (CAP Deusdad and Zafra, 2013; Bagnato et al., 2015; Deusdad et al., 2016b). 
In Greece and Italy, other changes have also been observed. Until 2008, the number of grey market migrant care workers had increased rapidly, the use of such workers becoming an important strategy for families to organise care for their older members in these countries (Bettio and Verashchagina, 2012; Ranci and Pavolini, 2013). This development had raised great concern about migrant workers' lacking job protection and social security. But now this trend has suddenly changed. In Greece, severe cuts in pensions and salaries have decreased family incomes significantly, especially in low-income households. As a result, employing a migrant care worker (or using formal care services) is no longer a viable option for the majority of families. Consequently, the responsibility for care of older people has reverted to the family, in practice, to female family members (CAP Vaiou and Siatitsa, 2013, p. 12). Also in Southern Italy, many families have been hit so hard by the economic crisis that they can no longer afford to employ a migrant care worker (called 'badante'). As a result, the employment opportunities of migrant women have been reduced considerably since 2008 (Bagnato et al., 2015).

The above described developments have deeply affected the relationship between formal and informal care in many European countries. Cuts in home-based and institutional care provisions have pushed responsibilities back to the family in different parts of Europe. The most radical setbacks have taken place in Southern Europe, where formal care provisions were developing when the economic crisis hit. Moreover, it was not just the development of formal care that was disrupted there - the expansion of grey market care work has also been affected, due to the economic problems of families. But also in other parts of Europe, cuts in institutional and home care provisions have pushed responsibility for care of older people back to families.

\section{CONCLUSION: DIRECTIONS OF POLICY CHANGE}

This chapter is based on the reports and working papers written by 11 national teams of the COST Action. The picture they paint is surprisingly consistent: recent developments are rather parallel in different parts of Europe, despite substantial differences in the starting point of the longterm care policy of individual nations before the economic recession. The overall conclusion is that European countries seem to be moving mostly in the same direction, though from different positions.

Using the framework of five key dimensions of change, as outlined in this chapter, the directions of recent long-term care policy change can be 
summarised as follows. On the first dimension, there has been a movement towards decentralisation in the implementation of care policy: more responsibility has been given to local and regional authorities. The central state has reduced its commitments in several European countries, also in financial terms, which means that the increase in the tasks transferred to local and regional governments has not been compensated by a growth in central funding. From countries like Denmark and the UK, there are also examples of the central state's growing control on the spending of local authorities. Overall, central governments seem to be trying to reduce their responsibility for long-term care - and to 'avoid blame' for its shortcomings (Sabatinelli and Semprebon, in this volume).

Concerning the complicated relation between social care and health care, that is, the second dimension, the direction is unclear. There have been some efforts, for example in the Slovak Republic and in some regions of Italy, to bring about more co-ordination or integration between these two sectors but these efforts have been mostly unsuccessful. The economic crisis has further complicated the collaboration: cuts have targeted the funding of health care as well as social care so both have been curtailing their provisions. This has changed some earlier practices: for example, the tendency in Southern Europe to compensate for the non-existence of social care by an overuse of health care has now decreased. However, the original problem, the lack of social care services, has not been resolved, nor have the difficulties in co-operation between social and health care.

Looking through the lens of the third dimension, new outsourcing practices adopted by public authorities have led to a distinctive decrease of 'inhouse' direct public provisions and to a corresponding growth of for-profit and non-profit provisions. Contracting out through competitive tenders seems to have strengthened the position of for-profit providers. Although many non-profit organisations are also providing these services, they have had to adapt to a new competitive context and adopt new market-based practices. In Southern Europe, where public budgets have been hit most severely by the economic crisis, non-profit organisations have seen a worsening of their contractual conditions with local and regional authorities, which reverberates also in the quality of their services and employment conditions.

Fourth, the widely adopted 'ageing in place' principle has not delivered on its promises in Europe. Based on this principle, institutional provisions have been cut in different parts of the continent but, as this has not been accompanied by major investments in home care provisions, long-term care has failed to meet people's needs. Access to home care has instead become stricter in several countries and the range of home care services has been narrowed. Long waiting lists for institutional care all around 
Europe are a result of this development, together with the emergence of residential quasi-services of questionable quality in some countries.

Finally, regarding the fifth dimension, the direction has clearly been away from formal care and towards informal care. As a consequence of cuts in institutional and home care services, families have been required to take increasing responsibility for the care of their older relatives. In this respect, the development seems to be parallel throughout Europe, from North to South and from West to East. A large proportion of needs are left to the family to deal with. The share of this family responsibility depends on the starting point at which national and local care systems entered the economic crisis: in the Nordic countries, publicly funded provisions still cover a sizeable proportion of needs, while in many in Southern and Eastern European countries the responsibility of families is currently very high.

Where does all this leave us? What is the state of long-term care in Europe after several years of deep economic recession? Based on the findings of the COST papers, the key directions of recent change are: from the central state to the local level, from public provision to for-profit (and non-profit) services, from institutional care to (insufficient) home care, and from formal care (and informal migrant care) to informal family care. Put together, these changes mean that governments in Europe are trying to reduce their responsibilities for care for their older populations, hoping that someone else will do the work and pay the bill.

\section{NOTES}

* The writing of this chapter has been partly supported by a project grant from the Academy of Finland (LinkAGE, No. 299053).

1. Newer revised versions of some of these COST Action papers and presentations have been published in 2016 in a special issue of the Journal of Social Service Research. In these cases, references are given to both the earlier versions and the newer published versions.

\section{REFERENCES}

Anttonen, A. and L. Häikiö (2014), 'Eldercare service redesign in six Finnish municipalities: welfare market in the making', unpublished paper presented at the COST Action IS1102 Workshop, Faculty of Economics and Business, Barcelona, 3-6 March.

Anttonen, A. and O. Karsio (2016), 'Eldercare service redesign in Finland: deinstitutionalization of long-term care', Journal of Social Service Research, 42 (2), 151-66.

Bagnato, A., S. Barillà and F. Martinelli (2014), 'The public supply of care for older 
people in Reggio Calabria. The impact of the crisis on a long-standing deficit', presentation at the COST Action IS1102 Workshop, Ekonomickà Univerzita, Bratislava, 3-7 November.

Bagnato, A., S. Barillà and F. Martinelli (2015), 'L'offerta pubblica di servizi di cura per gli anziani a Reggio Calabria. L'impatto della crisi su un deficit strutturale', paper presented at the ESPAnet Italy eighth conference, University of Salerno, Salerno, 17-19 September.

Bettio, F. and A. Verashchagina (2012), Long-Term Care for the Elderly: Provisions and Providers in 33 European Countries, Luxembourg: Publications Office of the European Union.

Bode, I. (2013), 'The changing governance of domiciliary elderly care in Germany', unpublished paper presented at the COST Action IS1102 Workshop, Dunarea de Jos University, Galati, 5-8 November.

Braun, V. and V. Clarke (2006), 'Using thematic analysis in psychology', Qualitative Research in Psychology, 3 (2), 77-101.

Burau, V. and T. Kröger (2004), 'The local and the national in community care: exploring policy and politics in Finland and Britain', Social Policy \& Administration, 38 (7), 793-810.

Colombo, F. and J. Mercier (2012), 'Help wanted? Fair and sustainable financing of long-term care services', Applied Economic Perspectives and Policy, 34 (2), 316-32.

Colombo, F., A. Llena-Nozal, J. Mercier and F. Tjadens (2011), Help Wanted? Providing and Paying for Long-Term Care, Paris: OECD Health Policy studies, OECD Publishing.

Deusdad, B. (2013), 'Regulatory trajectory and current organisational framework of social services and social care', COST Action IS1102 Working Papers, no. 1, accessed at http://www.cost-is1102-cohesion.unirc.it/docs/working-papers/wg1. spain-catalonia-social-services-b.deusdad.pdf.

Deusdad, B. and E. Zafra (2013), 'Older adults, housing accessibility and consequences of the economic crisis', unpublished paper presented at the COST Action IS1102 Workshop, Dunarea de Jos University, Galati, 5-8 November.

Deusdad, B., D. Comas-d'Argemir and S.F. Dziegielewski (2016b), 'Restructuring long-term care in Spain: the impact of the economic crisis on social policies and social work practice', Journal of Social Service Research, 42 (2), 246-62.

Deusdad, B., C. Pace and A. Anttonen (2016a), 'Facing the challenges in the development of long-term care for older people in Europe in the context of an economic crisis', Journal of Social Service Research, 42 (2), 144-50.

EC (1999), Social Protection for Dependency in Old Age in the 15 EU Member States and Norway, Luxembourg: Office for Official Publications of the European Communities.

Gambardella, D., E. Morlicchio and M. Accorinti (2013), 'L'illusione riformista delle politiche di assistenza in Italia', in Y. Kazepov and E. Barberis (eds), Il welfare frammentato. Le articolazioni regionali delle politiche sociali italiane, Roma: Carocci, pp. 25-44.

Garcés, J., F. Ródenas and T. Hammar (2013), 'Converging methods to link social and health care systems and informal care - confronting Nordic and Mediterranean approaches', in K. Liechsenring, J. Billing and N. Henk (eds), Long-Term Care in Europe: Improving Policy and Practice, London: Palgrave Macmillan, pp. 100-17.

Gori, C., J.L. Fernández and R. Wittenberg (eds) (2016), Long-Term Care Reforms in OECD Countries: Successes and Failures, Bristol: Policy Press. 
Hixon, L.L. (2016), 'The relationship between social and health services in care for older people', in C. Gori, J.L. Fernández and R. Wittenberg (eds), Long-Term Care Reforms in OECD Countries: Successes and Failures, Bristol: Policy Press, pp. 247-70.

Jensen, P.H. and B. Fersch (2013), 'Local variations and preferences in the organization of elder care: the Danish case', unpublished paper presented at the COST Action IS1102 Workshop, University of Iceland, Reykjavik, 3-7 June.

Kazepov, Y. (ed.) (2010), Rescaling Social Policies towards Multilevel Governance in Europe: Social Assistance, Activation and Care for Older People, Farnham: Ashgate Publishing.

Kispéter, E. and S. Yeandle (2015), 'Local welfare policy in a centralized governance system: childcare and eldercare services in a period of rapid change in Leeds', in D. Kutsar and M. Kuronen (eds), Local Welfare Policy Making in European Cities, Cham: Springer International Publishing, pp. 101-16.

Kováčová, J., G. Szüdi and S. Konečný (2014), 'Transformation of social services for the elderly in the context of deinstitutionalization of social services in Slovakia', unpublished paper presented at the COST Action IS1102 Workshop, University of Tampere, Tampere, 2-6 June.

Kröger, T. (2001), Comparative Research on Social Care: The State of the Art, Luxembourg: European Communities.

Kröger, T. (2011), 'Retuning the Nordic welfare municipality: central regulation of social care under change in Finland', International Journal of Sociology and Social Policy, 31 (3/4), 148-59.

Kröger, T. and A. Leinonen (2012), 'Transformation by stealth: the retargeting of home care services in Finland', Health and Social Care in the Community, 20 (3), 319-27.

Kröger, T. and S. Yeandle (eds) (2013), Combining Paid Work and Family Care: Policies and Experiences in International Perspective, Bristol: Policy Press.

Kröger, T., E. Leinonen and M. Kuronen (2013), 'Restructuring of care for older people in Jyväskylä', unpublished paper presented at the COST Action IS1102 Workshop, University of Iceland, Reykjavik, 3-7 June.

Kubalčíková, K. and J. Havlíková (2013), 'The current development of social services in the care of the older people: deinstitutionalization and/or marketization?', unpublished paper presented at the COST Action IS1102 Workshop, Dunarea de Jos University, Galati, 5-8 November.

Kubalčíková, K. and J. Havlíková (2016), 'Current developments in social care services for older adults in the Czech Republic: trends towards deinstitutionalization and marketization', Journal of Social Service Research, 42 (2), 180-98.

Kutsar, D. and M. Kuronen (eds) (2015), Local Welfare Policy Making in European Cities, Cham: Springer International Publishing.

Leichsenring, K. (2004), 'Developing integrated health and social care services for older persons in Europe', International Journal of Integrated Care, 4 (3), 1-15.

Leichsenring, K. and A. Alaszewski (eds) (2004), Providing Integrated Health and Social Care for Older Persons: A European Overview of Issues at Stake, Aldershot: Ashgate.

Leichsenring K., J. Billing and N. Henk (eds) (2013), Long-Term Care in Europe: Improving Policy and Practice, London: Palgrave Macmillan.

Martinelli, F. (2012), 'Current organisational framework of care services for older people - Italy', unpublished paper presented at the COST Action IS1102 Workshop, Rovira i Virgili University, Tarragona, 17-19 October. 
Mätzke, M. (2012), 'Regulatory trajectories and organisational frameworks of social services. Country profile - Germany', unpublished paper presented at the COST Action IS1102 Workshop, Oslo and Akershus University College, Oslo, 18 June.

Meagher, G. and M. Szebehely (eds) (2013), Marketisation in Nordic Eldercare: A Research Report on Legislation, Oversight, Extent and Consequences, Stockholm: Stockholm University (Stockholm Studies in Social Work 30).

Means, R. (2007), 'Safe as houses? Ageing in place and vulnerable older people in the UK', Social Policy \& Administration, 41 (1), 65-85.

Means, R., H. Morbey and R. Smith (2002), From Community Care to Market Care? The Development of Welfare Services for Older People, Bristol: Policy Press.

Pace, C. and S. Vella (2014), 'Impacts on Malta's welfare: causes, experiences and expectations', unpublished paper presented at the COST Action IS1102 Workshop, University of Tampere, Tampere, 2-6 June.

Pace, C., S. Vella and S.F. Dziegielewski (2016), 'Long-term care of older adults in Malta: influencing factors and their social impacts amid the international financial crisis', Journal of Social Service Research, 42 (2), 263-79.

Pfau-Effinger, B., L. Flaquer and P.H. Jensen (eds) (2009), Formal and Informal Work: The Hidden Work Regime in Europe, New York, USA and London, UK: Routledge.

Ranci, C. and E. Pavolini (eds) (2013), Reforms in Long-Term Care Policies in Europe, New York: Springer.

Ródenas, F., J. Garcés, I. Monsonís, C. García and A. Doñate-Martínez (2013), 'Case-management: social and health care for older people', unpublished paper presented at the COST Action IS1102 Workshop, Dunarea de Jos University, Galati, 5-8 November.

Rodrigues, R., M. Huber and G. Lamura (eds) (2012), Facts and Figures on Healthy Ageing and Long-term Care: Europe and North America, Vienna: European Centre for Social Welfare Policy and Research.

Sigurðardóttir, S.H. (2014), 'Older people with limitations - aging at home in Iceland', unpublished paper presented at the COST Action IS1102 Workshop, University of Tampere, Tampere, 2-6 June.

Sigurðardóttir, S.H. and I. Kåreholt (2014), 'Informal and formal care of older people in Iceland', Scandinavian Journal of Caring Sciences, 28 (4), 802-11.

Sigurðardóttir, S.H., O.H. Kristmundsson and S. Hrafnsdóttir (2016), 'Care of older adults in Iceland: policy objectives and reality', Journal of Social Service Research, 42 (2), 233-45.

Szüdi, G., J. Kováčová and S. Konečný (2016), 'Transformation of social care services for the elderly in Slovakia', Journal of Social Service Research, 42 (2), 199-217.

Timonen, V., M. Doyle and C. O'Dwyer (2012), 'Expanded, but not regulated: ambiguity in home-care policy in Ireland', Health and Social Care in the Community, 20 (3), 310-18.

Troisi, J. and H.J. von Kondratowitz (eds) (2013), Ageing in the Mediterranean, Bristol: Policy Press.

Vaiou, D. and D. Siatitsa (2013), 'Current organisational framework of elderly care services', COST Action IS1102 Working Papers, no. 2, accessed at http://www. cost-is1102-cohesion.unirc.it/docs/working-papers/wg1.greece-care-for-older-peo ple-d.vaiou-and-d.siatitsa.pdf. 
Yeandle, S. (2014), 'Reconfiguring services for older people living at home in Leeds, UK: how have services changed?', unpublished paper presented at the COST Action IS1102 Workshop, University of Tampere, Tampere, 2-6 June.

Yeandle, S. (2016), 'From provider to enabler of care? Reconfiguring local authority support for older people and carers in Leeds, 2008 to 2013', Journal of Social Service Research, 42 (2), 218-32.

Yeandle, S., T. Kröger, B. Cass, Y.-C. Chou, M. Shimmei and M. Szebehely, (2013), 'The emergence of policy supporting working carers: developments in six countries', in T. Kröger and S. Yeandle (eds), Combining Paid Work and Family Care: Policies and Experiences in International Perspective, Bristol: Policy Press, pp. 23-50. 